\title{
An analysis of financial protection before and after the Iranian Health Transformation Plan
}

\author{
Zhaleh Abdi, ${ }^{1}$ Justine Hsu, ${ }^{2}$ Elham Ahmadnezhad, ${ }^{1}$ Reza Majdzadeh ${ }^{1,3}$ and Iraj Harirchi ${ }^{4}$
}

${ }^{1}$ National Institute of Health Research; ${ }^{3}$ Department of Epidemiology and Biostatistics, School of Public Health; ${ }^{4}$ Cancer Research Centre of Cancer Institute, Tehran University of Medical Sciences, Tehran, Islamic Republic of Iran (Correspondence to: Zhaleh Abdi: zh-abdi@sina.tums.ac.ir). ${ }^{2}$ Department of Health Systems Governance and Financing, World Health Organization, Geneva, Switzerland.

\begin{abstract}
Background: Protecting people against the financial consequences of health-care payments is a key objective of health systems.

Aims: We carried out a descriptive analysis of changes in health spending associated with the implementation of the latest health sector reform in the Islamic Republic of Iran, the Health Transformation Plan (HTP).

Methods: The study relied on 2 rounds of data from the Household Expenditure and Income Survey (2014 and 2015). Key indicators of financial protection in health expenditure were estimated. The Kakwani index was used for out-of-pocket (OOP) health expenditure to measure the degree of progressivity in the distribution of such payments.

Results: Total OOP per capita health expenditure showed a 2.5\% relative decrease in real terms in 2015 compared to 2014 . Estimation of the Kakwani index suggested OOP spending became slightly more progressive over the time period of HTP reform. The share of the population facing catastrophic health expenditure also decreased significantly from $2.9 \%$ to $2.1 \%$ at the national level. However, the incidence of impoverishment due to OOP payments increased slightly between preand post-HTP, from $0.2 \%$ to $0.5 \%$.

Conclusion: Our findings suggest that the new policies have a positive association in improving financial protection against health costs among Iranians, albeit slightly less so for the poor. Future efforts to increase public spending for financial protection would be challenging and should rely on efficiency gains such as a move from fee-for-service to performance-based payment systems and more organized OOP collection mechanisms involving prepayment and risk pooling. Keywords: health expenditure, health equity, health policy, health transformation plan, Iran

Citation: Abdi Z; Hsu J Ahmadnezhad E; Majdzadeh R; Harirchi I. An analysis of financial protection before and after the Iranian Health Transformation Plan. East Mediterr Health J. 2019;26(9):1025-1033. https://doi.org/10.26719/emhj.19.026

Received: 01/03/18; accepted: 14/11/18

Copyright (c) World Health Organization (WHO) 2020. Some rights reserved. This work is available under the CC BY-NC-SA 3.o IGO license https://creativecommons.org/licenses/by-nc-sa/3.o/igo
\end{abstract}

\section{Introduction}

The design of health systems has a fundamental impact on population access to health services and thus their health status. Unfortunately, accessing these services can sometimes lead to some individuals having to pay catastrophic proportions of their available income and/ or push many into poverty (1-4). Globally it has been estimated that 150 million people suffer financial catastrophe each year due to health care payments and 100 million are pushed into poverty because of out-of-pocket (OOP) payments (5).

One of the main goals of a health system is fair financing, i.e. providing financial protection against the costs of ill-health. This concept of fairness or equity in health financing promotes the idea that the burden must be shared across society, and that individuals should be protected against financial hardship that threatens their living standards as a result of paying for health care $(6,7)$. Empirical evidence highlights that OOP payment is not only the most inequitable but also the least efficient means of financing health care (8). A more equitable and efficient health financing system requires effective health financing strategies that shift from a reliance on OOP payments at the time of service to more organized forms of revenue collection involving pre-payment and risk pooling mechanisms $(8,9)$. With the goals of financial protection and equity in mind, a number of countries have implemented health sector reforms and have reported promising results in reducing OOP payments. For instance, in Thailand, universal coverage was launched in 2001 to ensure equitable access to health care for the entire population. Since its introduction, the policy had a major impact on reducing the overall incidence of catastrophic expenditure among population (10). In Turkey, following the implementation of the health transformation programme in 2003, which aimed at reducing total OOP expenditure and increasing access to health care, there was a diminishing trend in catastrophic and impoverishing health expenditures (11). Similarly, Indonesia implemented a reform to restructure its health care financing system and improve access to health services by establishing several health insurance programmes, which were relatively successful in providing financial protection for their members against the cost of medical services (12).

In the Islamic Republic of Iran, major sources of financing the health sector are OOP health expenditures 
and government expenditures, which respectively represented $47.0 \%$ and $38.9 \%$ of total health spending in 2013 (13). Social health insurance accounted for $19.7 \%$ of total health spending. In recognition of the Iranian health system being predominantly financed by OOP payments, the country's fifth 5-year development plan has mandated the government to decrease the share of such payments in total health expenditures to $30 \%$ or less (14). In addition, with the aim of ensuring that health care is more accessible and its provision more equitable to the population, the 11th government launched the health transformation plan (HTP) in May 2014 (15). One of the major aims of this plan is to reduce OOP payments, a target which is mainly supported by a substantial increase in the budget of the Ministry of Health and Medical Education (i.e. 59\% increase in annual budget), financed from a targeted energy subsidies law and an earmarked $1 \%$ of value added tax, together contributing an additional US\$ 3 billion (16).

Protecting the population against the impact of high OOP payments is an important goal of the HTP. First, insurance coverage was extended for approximately 10 million people (17). Recognising that spending on inpatient services and medicines are the main components of total OOP expenditure, the Ministry of Health and Medical Education also took major steps to reduce inpatient costs by reducing co-payments for hospitals affiliated with the Ministry of Health and Medical Education to a maximum of $10 \%$ for residents of large and medium cities and a maximum of $5 \%$ for residents of rural areas. These co-payment rates were reduced to $6 \%$ and $3 \%$ respectively at the end of 2014. In addition, modification of the tariffs paid for medical services started in November 2014. The main objective of revising health tariffs was to regulate physicians' payments and reduce informal payments, which are estimated to be high (18). The HTP also reduced the shortage of essential drugs stemming from international sanctions against the Islamic Republic of Iran, and reduced the price of medicines at the beginning of 2014.

In this study, we aimed to analyse preliminary changes observed around the time of the implementation of the HTP, particularly in regard to changes in the level and distribution of OOP payments and catastrophic and impoverishing health expenditures by comparing 1 year before and after implementation. Equity in the distribution of such payments was also examined to understand the degree of progressivity.

\section{Methods}

Data are from 2 rounds of the Household Expenditure and Income Survey, which is conducted 4 times a year by the Iranian Statistics Centre. Each round is nationally representative, and our analysis relied on data from the Persian calendar's winter season, corresponding to Gregorian calendar months January-April 2013 (sample size 9535 households) and from January-April 2015 (sample size 9543 households). Since the HTP was initiated in
April 2014, and with expenditure recall periods of a maximum of 1 year, the majority of data thus represents the period of a year before and a year after the implementation of reforms.

Health expenditures refer to OOP payments made by individuals to health providers at the time of service use. They include direct payments (including gratuities and payments in kind) to formal medical professionals, informal traditional or alternative healers, clinics, health centres and pharmacies and exclude prepayment for health services (e.g. in the form of taxes or specific insurance premiums or contributions) and, where possible, are net of any reimbursements to the individual who made the payments. All expenditure variables were annualized and baselined to 2011, adjusting for urban and rural inflation rates based on an annual average of quarterly consumer price indices.

Key indicators of financial protection in health spending concern catastrophic and impoverishing health expenditures, where the former is concerned with the impact of health expenditures causing a person to forego spending on other necessities and the latter is concerned with health expenditures pushing a person below the poverty line. Indicators were constructed following established methods. For catastrophic health expenditures, the methodology developed by the World Health Organization (WHO) was applied when catastrophic health expenditures were equal to or exceeded $40 \%$ of a household's capacity to pay (19). The WHO approximates capacity-to-pay as total expenditure net of nondiscretionary food spending. The latter is estimated as the average food expenditure per equivalent adult across households in the 45th-55th percentile of the food budget share distribution. When actual food spending is below this amount, capacity-to-pay is defined as total expenditure net of actual food spending. Health expenditures are considered impoverishing when they push a person below the poverty line, i.e. expenditures gross of spending on health are above the poverty line but expenditures net of health spending are below the line. In this analysis, the international poverty line of US $\$ 1.90$ (2011 purchasing power parity) per capita, per day was used. Population headcount ratios were estimated for both indicators and t-tests conducted to assess whether changes were significant or not.

Equity in the distribution of OOP payments was also analysed by estimating the Kakwani index. This index is based on the Gini coefficient of income and the concentration index of OOP expenditures (20). A Gini index ranks income distribution on a scale between 0 and 1 , where 0 indicates perfect equality and 1 indicates perfect inequality. We proxied income using total consumption expenditure. A concentration index assesses the distribution of OOP payments across the population taking a value between -1 and 1 , where a negative value suggests OOP is concentrated in the poor and a positive value suggests OOP is concentrated in the rich. The Kakwani index is then the difference between the Gini coefficient and the concentration index for OOP 
health payments, and ranges from -2 (indicating severe regressivity) to +1 (indicating strong progressivity). If OOP payments are a progressive way to finance the health services, the Kakwani index will have a positive value. This research analysed changes in the degree of progressivity in OOP financing in the 2 time periods associated with the HTP reform.

\section{Results}

One of the main objectives of the HTP is to reduce OOP health payments, especially those due to inpatient costs in public hospitals, across the Iranian population. Table 1 shows total OOP and OOP payments on inpatient services before and after HTP implementation. The results indicate a positive association with a relative decrease in total OOP per capita expenditure of $2.5 \%$ in real terms at the national level (from 2099569 rials to 2047120 rials). Almost all subpopulation groups benefited from the reduction in total OOP expenditure except for the richest quintile and those living in urban areas. The more vulnerable groups of the population, those living in rural areas and the poorest, benefitted from the greatest relative reduction in total OOP expenditure.
The Iranian HTP had an initial focus on reducing inpatient costs in public hospitals. The Household Expenditure and Income Survey collected data on spending on inpatient health services (covering both public and private sectors). Table 1 also shows that OOP on inpatient services per capita decreased in the year after HTP compared with the year before HTP at the national level, from 429323 rials to 288310 rials, representing a $32.8 \%$ relative reduction. All subnational population groups saw a decrease, with the greatest relative change observed for middle socioeconomic status populations: quintile $3(-39.7 \%)$ and quintile $4(-46.8 \%)$, followed by those in rural areas $(-38.8 \%)$.

Examining OOP payments reveals that the positive impact of the HTP on inpatient spending seems to be counter-balanced by the opposite effect on other outpatient fees and services (Figure 1). The focus of the HTP on inpatient services and medicines saw a reduction in related OOP expenditures. However, OOP on outpatient fees increased, as did such payments for ancillary services and dentistry.

This increase, however, was not observed for all subnational population groups. Figure $1 \mathrm{~b}$ shows that for the poorest quintile OOP payments for services (with the exception of ancillary services) decreased,

\begin{tabular}{|c|c|c|c|c|c|c|c|c|}
\hline \multirow{3}{*}{$\begin{array}{l}\text { Area or } \\
\text { quintile }\end{array}$} & \multicolumn{4}{|c|}{ Total OOP } & \multicolumn{4}{|c|}{ Inpatient OOP } \\
\hline & \multicolumn{2}{|c|}{$\begin{array}{c}\text { Population mean; (confidence } \\
\text { interval) }\end{array}$} & \multirow{2}{*}{$\begin{array}{c}\text { Relative } \\
\text { change } \\
(\%)\end{array}$} & \multirow[t]{2}{*}{$\begin{array}{l}\text { Absolute } \\
\text { change }\end{array}$} & \multicolumn{2}{|c|}{$\begin{array}{c}\text { Population mean; (confidence } \\
\text { interval) }\end{array}$} & \multirow{2}{*}{$\begin{array}{c}\text { Relative } \\
\text { change } \\
(\%)\end{array}$} & \multirow[t]{2}{*}{$\begin{array}{c}\text { Absolute } \\
\text { change }\end{array}$} \\
\hline & 2014 & 2015 & & & 2014 & 2015 & & \\
\hline National & $\begin{array}{c}2099569 \text {; } \\
(1991382- \\
2207755)\end{array}$ & $\begin{array}{c}2047 \text { 120; } \\
(1841276- \\
2252963)\end{array}$ & -2.5 & -52448 & $\begin{array}{c}429323 ; \\
(387962- \\
470683)\end{array}$ & $\begin{array}{c}288 \text { 309; } \\
(250610- \\
326008)\end{array}$ & -32.8 & $-141013^{* * *}$ \\
\hline Urban & $\begin{array}{l}2408 \text { 992; } \\
(2241114- \\
2576871)\end{array}$ & $\begin{array}{c}2431556 ; \\
(2090422- \\
2772691)\end{array}$ & 0.9 & 22563 & $\begin{array}{c}485648 \\
(422187-549109)\end{array}$ & $\begin{array}{c}332 \text { 273; } \\
(272 \text { 244- } \\
392 \text { 303) }\end{array}$ & 31.6 & $-153374^{* *}$ \\
\hline Rural & $\begin{array}{c}1311841 ; \\
(1204820- \\
1418862)\end{array}$ & $\begin{array}{c}1055955 ; \\
\text { (980 911.3- } \\
1130999 \text { ) }\end{array}$ & -19.5 & $-255886^{* *}$ & $\begin{array}{c}285930 ; \\
(241443-330418)\end{array}$ & $\begin{array}{l}174 \text { 959; (1438 877- } \\
206042)\end{array}$ & -38.8 & $-110971^{* * *}$ \\
\hline Q1 & $\begin{array}{c}438 \text { 865.2; } \\
(409 \text { 112.6- } \\
468 \text { 617.9) }\end{array}$ & $\begin{array}{c}369 \text { 734; } \\
(342 \text { 403- } \\
397064.9)\end{array}$ & -15.8 & $-69131^{*}$ & $\begin{array}{c}83593 ;(69476- \\
97710)\end{array}$ & $\begin{array}{c}57278 ;(43934- \\
70621)\end{array}$ & -31.5 & -26315 \\
\hline Q2 & $\begin{array}{c}812659.5 \\
(760721.4- \\
864597.7)\end{array}$ & $\begin{array}{c}764 \text { 072.3; } \\
\left(709819.5^{-}\right. \\
818 \text { 325.1) }\end{array}$ & -6.0 & -48587 & $\begin{array}{c}160437 ;(131542- \\
189332)\end{array}$ & $\begin{array}{c}137876 ; \\
(109626-166127)\end{array}$ & -14.1 & -22560 \\
\hline Q3 & $\begin{array}{c}1312266 ; \\
(1227578- \\
1396954)\end{array}$ & $\begin{array}{c}1127 \text { 601; } \\
(1040901- \\
1214302)\end{array}$ & -14.1 & $-184664^{*}$ & $\begin{array}{c}297 \text { 044; } \\
(251250- \\
342838)\end{array}$ & $\begin{array}{l}179241 ;(136798- \\
221685)\end{array}$ & -39.7 & $-117802^{* *}$ \\
\hline $\mathrm{Q}_{4}$ & $\begin{array}{c}2223898 \text {; } \\
(2049588- \\
2398208)\end{array}$ & $\begin{array}{c}1888 \text { 749; } \\
(1744725- \\
2032773)\end{array}$ & -15.1 & -335148 & $\begin{array}{c}541328 ; \\
(434074- \\
648582)\end{array}$ & $\begin{array}{c}287844 \\
(227972-347717)\end{array}$ & -46.8 & $-253483^{*}$ \\
\hline Q5 & $\begin{array}{c}5716025 \\
(5164361- \\
6267689)\end{array}$ & $\begin{array}{c}6095431 ; \\
(4920629- \\
7270232)\end{array}$ & 6.6 & 379405 & $\begin{array}{l}1065280 \\
(867278- \\
1263282)\end{array}$ & $\begin{array}{c}780481 \\
(580108- \\
980 \text { 854) }\end{array}$ & -26.7 & -284798 \\
\hline
\end{tabular}

Expenditure variables were annualized and baselined to 2011, adjusting for urban and rural inflation rates based on an annual average of quarterly consumer price indices. Quintiles are constructed based on per capita consumption expenditure.

${ }^{*} \mathrm{P}<0.05,{ }^{* *} \mathrm{P}<0.01,{ }^{* * *} \mathrm{P}<0.001$. 
Figure 1 Out-of-pocket payments in the Islamic Republic of Iran according to type of health spending

\section{a. National averages}

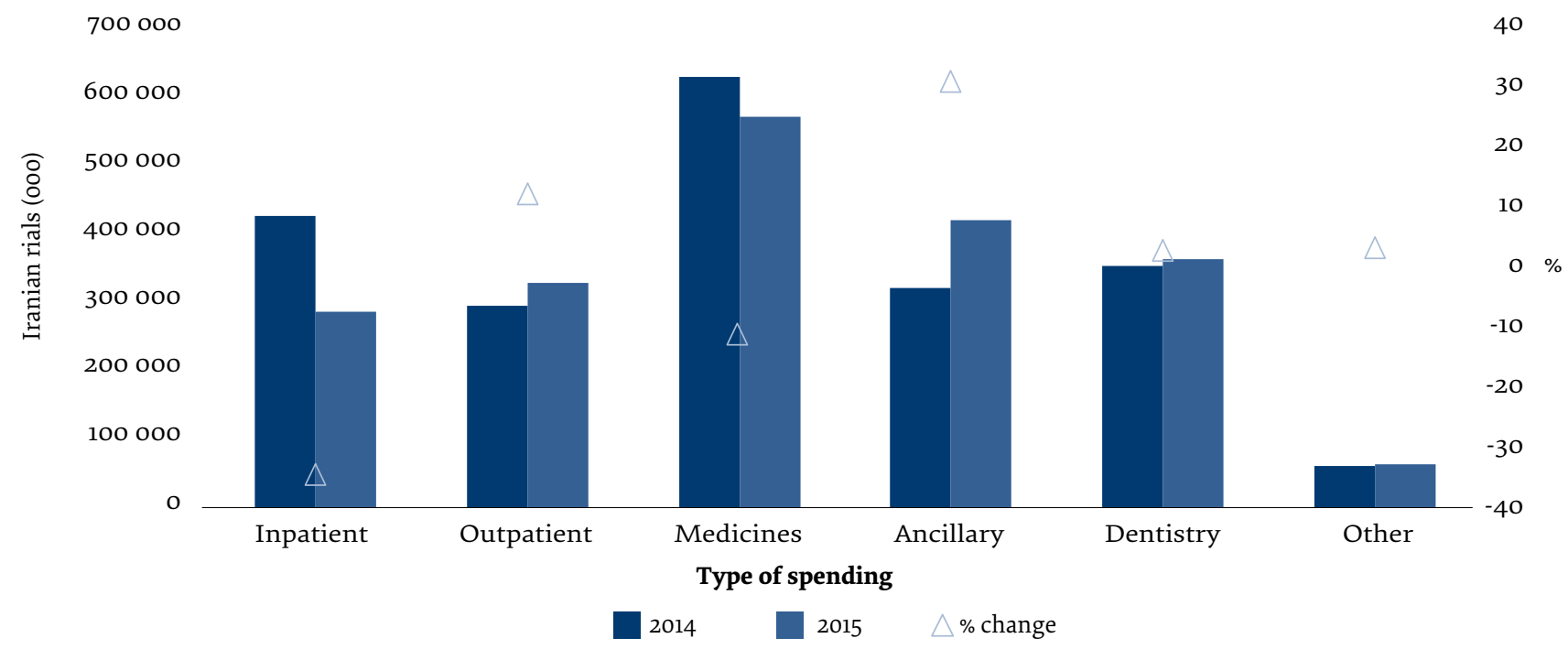

\section{b. Quintile 1}

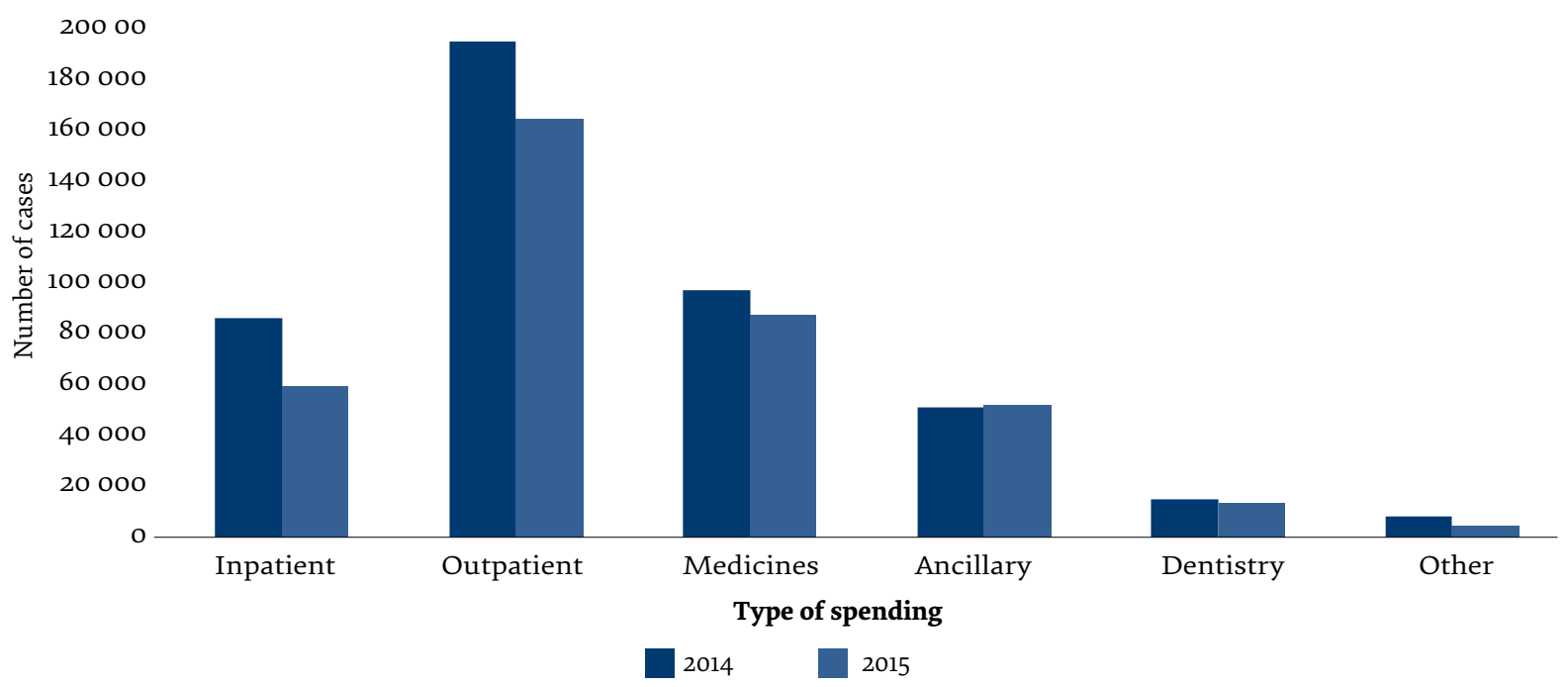

\section{c. Quintile 5}

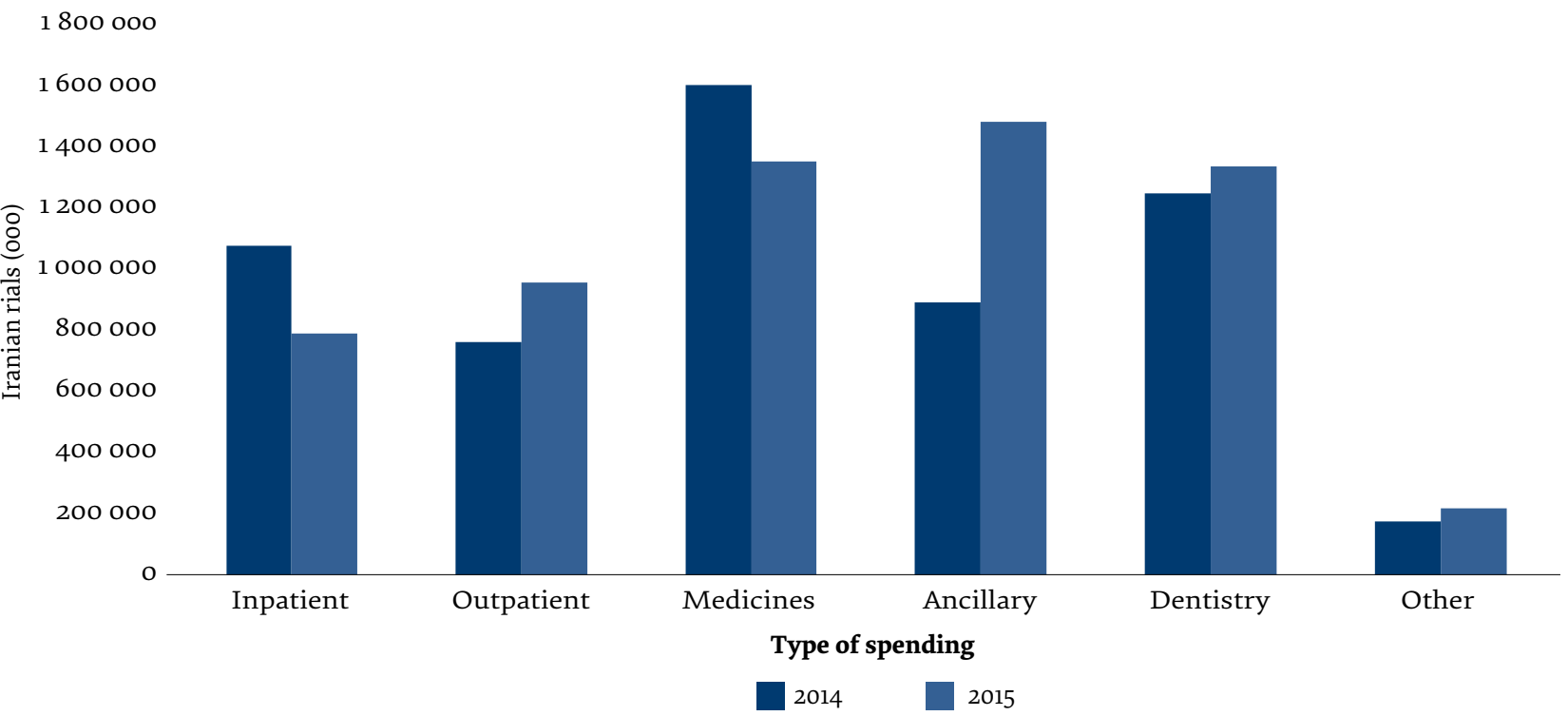


whereas Figure 1c shows that for the richest quintile OOP payments increased for outpatient fees, ancillary services and dentistry during the same period.

To understand the impact of OOP health spending on living standards, catastrophic health expenditures was calculated following the WHO capacity-to-pay approach. Comparison of the share of the population experiencing catastrophic health expenditures showed there was a statistically significant reduction after the implementation of the HTP (Table 2), decreasing from $2.9 \%$ to $2.1 \%$. More importantly, all population groups benefitted from this reduction, although the richest $40 \%$ of the population and those in urban areas benefitted the most with greater absolute decreases. In terms of impoverishing health expenditure using the US\$1.90 international poverty line in 2011 purchasing power parity, the incidence of impoverishment due to OOP payments increased slightly.

Table 3 shows the distributional analysis with estimations for the Gini coefficient for total expenditure, the concentration index for OOP payments and the Kakwani index. The Gini coefficient for total expenditure was estimated as 0.38 in 2014 and 0.39 in 2015, suggesting that the distribution generally remained the same after the implementation of the HTP. The concentration index for OOP payments was estimated as 0.49 in 2014 and rose to 0.55 in 2015, suggesting that such payments were more concentrated in the wealthy than in the poor. The Kakwani index is the difference between the two and was estimated to be 0.12 in 2014, rising to 0.15 in 2015. The positive index indicates OOP was already a progressive source of financing pre-reforms, and the slight increase suggests an increase in the degree of progressivity of $\mathrm{OOP}$ as a source of financing.

\section{Discussion}

This analysis presents preliminary results observed during the implementation of the Iranian HTP, including changes in the level and distribution of OOP and catastrophic and impoverishing health expenditures across the population. Preliminary results indicate that the HTP is associated with reductions in OOP and catastrophic health expenditures. Our results are consistent with those of similar studies that reported a reduction in

Table 2 Key indicators of financial protection in health spending, Islamic Republic of Iran

\begin{tabular}{|c|c|c|c|c|c|c|}
\hline \multirow[t]{3}{*}{ Area or quintile } & \multicolumn{3}{|c|}{ Catastrophic health expenditures ${ }^{a}(\%)$} & \multicolumn{3}{|c|}{ Impoverishing health expenditures ${ }^{\mathrm{b}}(\%)$} \\
\hline & \multicolumn{2}{|c|}{ Headcount ratio } & \multirow[t]{2}{*}{ Absolute change ${ }^{c}$} & \multicolumn{2}{|c|}{ Headcount ratio } & \multirow{2}{*}{$\begin{array}{c}\text { Absolute } \\
\text { change }^{c}\end{array}$} \\
\hline & 2014 & 2015 & & 2014 & 2015 & \\
\hline \multicolumn{7}{|l|}{ Area } \\
\hline National & 2.9 & 2.1 & $-0.8^{*}$ & 0.2 & 0.5 & $0.3^{* *}$ \\
\hline Urban & 2.6 & 1.7 & $-0.9^{*}$ & 0.1 & 0.1 & 0.0 \\
\hline Rural & 3.8 & 3.2 & -0.5 & 0.6 & 1.5 & $0.9^{* * *}$ \\
\hline \multicolumn{7}{|l|}{ Quintile } \\
\hline Q1 & 2.3 & 2.2 & -0.1 & 1.1 & 2.2 & $1.1^{* *}$ \\
\hline Q2 & 2.1 & 1.5 & -0.6 & 0.0 & 0.1 & 0.1 \\
\hline Q3 & 2.1 & 1.7 & -0.4 & 0.0 & 0.0 & \\
\hline $\mathrm{Q}_{4}$ & 3.4 & 2.2 & -1.3 & 0.0 & 0.0 & \\
\hline $\mathrm{Q}_{5}$ & 4.9 & 3.3 & -1.6 & 0.0 & 0.0 & \\
\hline
\end{tabular}

${ }^{*} \mathrm{P}<0.05,{ }^{* *} \mathrm{P}<0.01,{ }^{* * *} \mathrm{P}<0.001$.

${ }^{a}$ Defined as $40 \%$ or more of nonsubsistence food expenditure.

${ }^{b}$ Using the 2011 international poverty line of US\$1.90 purchasing power parity.

subject to rounding.

\begin{tabular}{lcccc}
\hline Table 3 Distributional analyses of out-of-pocket payments & & & \\
Year and index & Estimate & Standard error & P >t & $\mathbf{9 5 \%} \mathbf{C I}$ \\
$\mathbf{2 0 1 4}$ & & & & 0.0001 \\
$\quad$ Gini coefficient & 0.38 & 0.0053 & 0.0001 & $0.366-0.387$ \\
$\quad$ Concentration index & 0.49 & 0.0182 & 0.0001 & $0.459-0.530$ \\
Kakwani index & 0.12 & 0.0179 & & $0.083-0.153$ \\
$\mathbf{2 0 1 5}$ & & & 0.0001 & $0.381-0.406$ \\
$\quad$ Gini coefficient & 0.39 & 0.0065 & 0.0001 & $0.459-0.632$ \\
Concentration index & 0.55 & 0.0442 & 0.0002 & $0.073-0.231$ \\
$\quad$ Kakwani index & 0.15 & 0.0403 & &
\end{tabular}


the proportion of households experiencing catastrophic health expenditure following the implementation of health reforms (10-12). Distributional analyses also suggest that there were progressive changes in the nature of OOP financing. Impoverishing health expenditures increased slightly, but general poverty levels did as well (21).

These initial positive results can be linked with a number of interventions of the HTP. One of the main interventions was the extension of free basic health insurance to all uninsured Iranians by the Iranian Health Insurance Organization. Government reports and household surveys suggest an increase in population coverage from $83.2 \%$ to $90.1 \%$ (22). During the first year of HTP, co-payments for inpatient services were reduced for hospitals affiliated with the Ministry of Health and Medical Education from 10\% to 6\% for urban areas and from $5 \%$ to $3 \%$ for rural areas. In terms of purchasing health services, tariffs paid by the Iranian Health Insurance Organization to health facilities for the provision of health services were increased in November 2014 to better reflect the cost of services provided. The main objectives of such initiatives were to regulate provider payments and reduce informal payments, which had been estimated to be high (18). These reforms in provider payments along with the tighter regulation of what public hospitals could charge patients all aimed to reduce OOP and informal (under-the-table) payments in public hospitals.

Our analyses further demonstrated that the decrease in OOP payments for inpatient services was partially counterbalanced by a slight increase for OOP payments on various outpatient services. Considering the fact that most of the HTP interventions targeted the inpatient sector in the first year of HTP implementation, this initial trend was expected. Relatively higher OOP spending on outpatient care was observed for wealthier population groups and on services related to ancillary and dentistry care.

The distributional analyses of OOP spending showed this to be a progressive source of financing in the country and with OOP payments mainly concentrated among the rich. A similar study conducted in Turkey found that OOP payment was progressive in the first year of the health reform and it tended to be regressive 6 years afterwards (11). In countries of the Organisation for Economic Cooperation and Development (OECD), the analysis of progressivity using the Kakwani index revealed that, although health care payments were almost proportional to ability to pay, private payments included, OOP payments and private insurance premiums were highly regressive (23). Several studies in low- to middle-income countries reported that OOP payments were a regressive financing mechanism (24-26). Given the Iranian health system is predominantly financed by OOP payments, it would be important to explore mechanisms to transform the collection of such resources from individuals at the time of service use to more organized collection forms involving pre-payment and risk-pooling.
In this study, the share of the population experiencing catastrophic health expenditures decreased from $2.9 \%$ to $2.1 \%$ over 2 time periods. More importantly, all population groups benefitted from this reduction, although the richest $40 \%$ of the population and those in urban areas benefitted the most with greater absolute decreases, suggesting that the observed reductions in OOP payments in the poor were not as effective in reducing their levels of catastrophic health expenditures in comparison with those population. Strategies aimed at improving financial access for the poor should pursue equity gains by improving financial protection for those harder to reach population groups. The increase in the incidence of impoverishment before and after HTP might be a reflection of the general poverty levels in the Islamic Republic of Iran, which also slightly increased over the same period, from $1.7 \%$ to $3.4 \%$ (21). As expected, impoverishment was only observed in the poorest quintiles.

Key strengths and limitations of this study are worth noting. First, the study relied on a robust and comprehensive national household survey conducted by the Iranian Statistics Centre. Second, the methods used for analysing financial protection are well established, dating back to the 1990s and used in several other country studies (27-29). Some limitations to note are that the study could not isolate the impact of the HTP, which would have required either a randomized control study or a quasi-experimental model. Working with policymakers to conduct more rigorous impact evaluations in the future would be welcome. Additionally, the relatively short time period covered by the study does not allow for full understanding of the impact of the reform and thus, regular monitoring and evaluation are strongly recommended. Nevertheless, this study still presents important preliminary findings of changes associated with reforms. It provides timely insight to inform the future direction of HTP.

\section{Conclusion}

This study provides preliminary evidence regarding the level and distribution of OOP payments, as well as their catastrophic and impoverishing effects during a period before and after implementation of the latest health sector reform in the Islamic Republic of Iran. Results suggest that the new policies are associated with a positive impact in reducing total OOP expenditure. Catastrophic health expenditures also decreased for all subnational population groups, albeit slightly less so for the poor. In addition, impoverishing health expenditures slightly increased for the poor and near-poor. The results thus suggest efficiency rather than equity improvement was made as the reduction in OOP was less effective in extending financial protection for these more vulnerable groups. The distribution of OOP was progressive preHTP and slightly increased post-HTP.

\section{Funding: None.}

Competing interests: None declared. 


\section{Analyse de la protection financière avant et après le plan national de transformation du secteur de la santé en République islamique d'Iran}

\section{Résumé}

Contexte : La protection de la population contre les conséquences financières des paiements de soins de santé est un objectif essentiel des systèmes de santé.

Objectifs : Nous avons mené une analyse descriptive des changements dans les dépenses de santé liés à la mise en œuvre de la dernière réforme du secteur de la santé en République islamique d'Iran, connu sous le nom de plan national de transformation du secteur de la santé.

Méthodes : La présente étude s'est appuyée sur deux séries de données issues de l'enquête sur les dépenses et les revenus des ménages (2014 et 2015). Les principaux indicateurs de la protection financière en matière de dépenses de santé ont été évalués. L'indice de Kakwani a été utilisé pour les dépenses de santé à la charge des patients afin de mesurer le degré de progressivité dans la distribution de ces paiements.

Résultats : En 2015, le montant total des dépenses de santé non remboursées par habitant a enregistré une diminution en valeur réelle de 2,5\% par rapport à 2014. D'après l'estimation de l'indice de Kakwani, les dépenses de santé non remboursées sont devenues légèrement plus progressives sur la période du plan national de transformation du secteur de la santé. Au niveau national, la part de la population confrontée à des dépenses de santé catastrophiques a également diminué de manière significative, de $2,9 \%$ à $2,1 \%$. Cependant, l'incidence de l'appauvrissement dû aux dépenses de santé directement à la charge des patients a légèrement augmenté, de $0,2 \%$ à $0,5 \%$ avant et après le plan national de transformation du secteur de la santé, respectivement.

Conclusion : D'après nos observations, les nouvelles politiques ont participé à l'amélioration de la protection financière contre le coût des soins de santé dans la population iranienne, bien que l'effet soit moins marqué chez les habitants les plus pauvres. À l'avenir, les efforts d'augmentation des dépenses publiques en faveur de la protection financière devraient être ambitieux et s'appuyer sur des gains d'efficacité, par exemple en passant d'un système de paiement à l'acte à un système axé sur le rendement, ou en améliorant l'organisation des mécanismes de recouvrement des dépenses de santé non remboursées grâce au paiement anticipé et à la répartition des risques.

$$
\begin{aligned}
& \text { تحليل الحماية المالية قبل خطة التحول الصحي في جمهورية إيران الإسالامية وبعدها }
\end{aligned}
$$

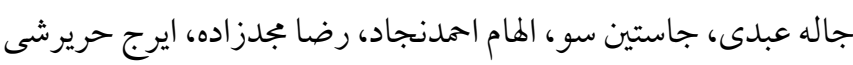

الخلفية: تُعتبر حماية الناس من التعرض للعو اقب المالية التي تترتب على المدفوعات في مجال الرعاية الصحية أحد الأهداف الرئيسية للنظم الصحية.

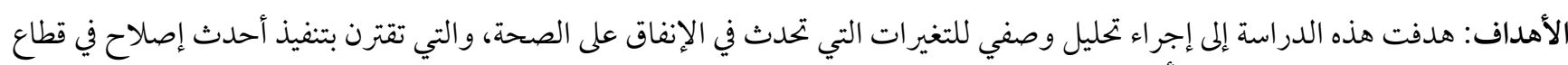

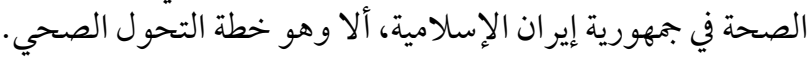

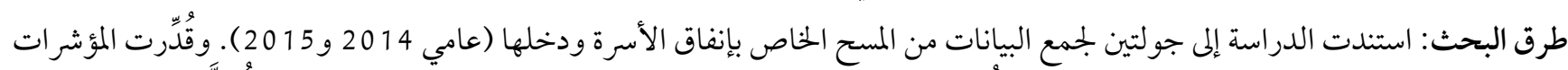

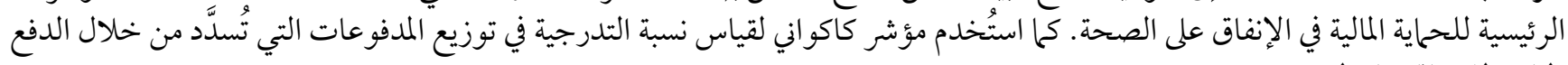
المباشر للإنفاق على الصحة. للمالية الإنفاق

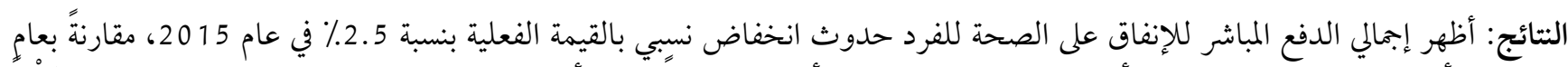

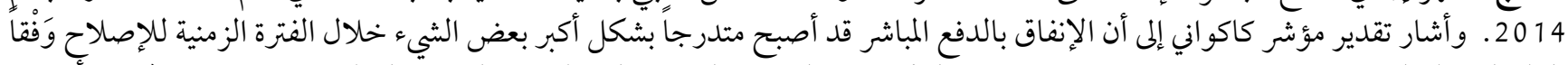

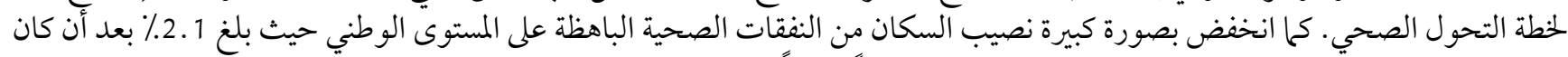

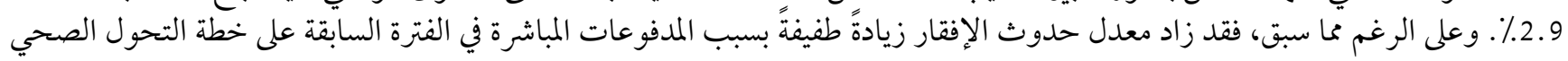

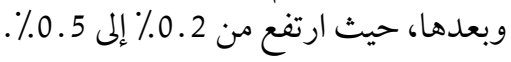

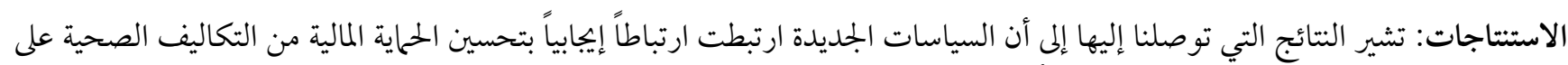

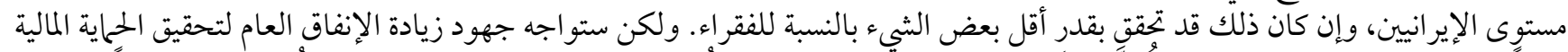

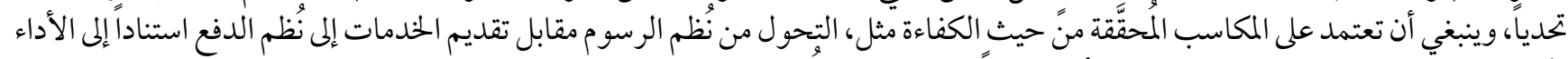

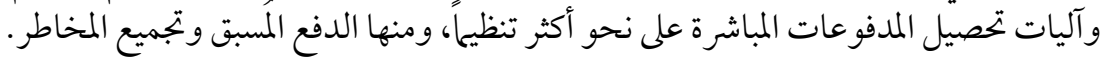




\section{References}

1. Van Doorslaer E, O'Donnell O, Rannan-Eliya RP, Somanathan A, Adhikari SR, Garg CC, et al. Effect of payments for health care on poverty estimates in 11 countries in Asia: an analysis of household survey data. Lancet. 2006;368(9544):1357-64. PMID:17046468

2. McIntyre D, Thiede M, Dahlgren G, Whitehead M. What are the economic consequences for households of illness and of paying for health care in low-and middle-income country contexts? Soc Sci Med. 2006;62(4):858-65. PMID:16099574

3. Garg CC, Karan AK. Reducing out-of-pocket expenditures to reduce poverty: a disaggregated analysis at rural-urban and state level in India. Health Policy Plan. 2009;24(2):116-28. PMID:19095685

4. Kruk ME, Goldmann E, Galea S. Borrowing and selling to pay for health care in low-and middle-income countries. Health aff. 2009;28(4):1056-66. PMID:19597204

5. Xu K, Evans DB, Carrin G, Aguilar-Rivera AM, Musgrove P, Evans T. Protecting households from catastrophic health spending. Health aff. 2007;26(4):972-83. PMID:17630440

6. Murray CJL, Xu K, Klavus J, Kawabata K, Hanvoravongchai P, Zeramdini R, et al. Assessing the distribution of household financial contributions to the health system: concepts and empirical application, Ch. 38. In: Murray CJL, Evans DB, eds. Health systems performance assessment: debates, methods and empiricism. Geneva: World Health Organization; 2003: 513-31.

7. Ekman B. Catastrophic health payments and health insurance: Some counterintuitive evidence from one low-income country. Health policy. 2007;83(2):304-13. PMID:17379351

8. The world health report 2000: health systems: improving performance. Geneva: World Health Organization; 2000.

9. Kutzin J. A descriptive framework for country-level analysis of health care financing arrangements. Health Policy. 2001;56(3):171-204. PMID:11399345

10. Limwattananon S, Tangcharoensathien V, Prakongsai P. Catastrophic and poverty impacts of health payments: results from national household surveys in Thailand. Bull World Health Organ. 2007;85(8):600-6. PMID:17768518

11. Yardim MS, Cilingiroglu N, Yardim N. Financial protection in health in Turkey: the effects of the Health Transformation Programme. Health Policy Plan. 2014;29(2):177-92. PMID:23411120

12. Aji B, De Allegri M, Souares A, Sauerborn R. The impact of health insurance programs on out-of-pocket expenditures in Indonesia: an increase or a decrease? Environ Res Public Health. 2013;10(7):2995-3013. PMID:23873263

13. National Health Accounts Report, 2013. Tehran: National Statistics Center; 2014.

14. The fifth five-year developmental plan of I.R. of Iran (2011-2015). Tehran: Islamic Parliament of Iran; 2016 (http://parliran.ir/ index.aspx?siteid=1\&siteid=1\&pageid=3362.\%20Accessed\%20December\%2010,\%202015, accessed 2 July 2016).

15. Moradi-Lakeh M, Vosoogh-Moghaddam A. Health sector evolution plan in Iran; equity and sustainability concerns. Int J Health Policy Manag. 2015;4(10):637. PMID:26673172

16. Assessment of national annual budget of health sector. Islamic Parliament Research Center (IPRC); 2015.( http://rc.majlis.ir/fa/ report/show/916417, accessed July 5 2016).

17. MP hails government's national health plan. Islamic Republic News Agency (IRNA). (http://www.irna.ir/en/News/82128592, accessed 20 April 2016).

18. Nekoeimoghadam M, Esfandiari A, Ramezani F, Amiresmaili M. Informal payments in healthcare: a case study of Kerman province in Iran. Int J Health Policy Manag. 2013;1(2):157. PMID:24596856

19. Xu K. Distribution of health payments and catastrophic expenditures methodology. Geneva: World Health Organization; 2005.

20. Kakwani NC. Measurement of tax progressivity: an international comparison. The Economic J. 1977;87(345):71-80.

21. Poverty and equity data (Iran's profile). Washington DC: World Bank; (http://povertydata.worldbank.org/poverty/country/IRN, accessed 20 June 2016).

22. Ali Akbari Saba R, Safakish M, Rezaie Ghahroodi Z, Khabiri Nemati R, Zahedian AR, Khosravi A, et al. Utilization of health services in 2014.Tehran: Ministry of Health and Medical Education Press; 2017.

23. De Graeve D, Van Ourti T. The distributional impact of health financing in Europe: A review. World Economy. 2003;26(10):14591479.

24. Makinen $\mathrm{M}$, et al. Inequalities in health care use and expenditures: empirical data from eight developing countries and countries in transition. Bull World Health Organ. 2000;78 (1):55-65. PMID:10686733

25. Leive A, Xu K. Coping with out-of-pocket health payments: empirical evidence from 15 African countries. Bull World Health Organ, 2008. 86 (11): 849-56C. PMID:19030690

26. Akazili J, et al. Progressivity of health care financing and incidence of service benefits in Ghana. Health Policy Plan. 2012; 27(suppl 1):i13-i22. PMID:22388496

27. Li Y, Wu Q, Liu C, Kang Z, Xie X, Yin H, et al. Catastrophic health expenditure and rural household impoverishment in China: what role does the new cooperative health insurance scheme play? PLoS One. 2014;9(4):e93253. PMID:24714605 
28. Buigut S, Ettarh R, Amendah DD. Catastrophic health expenditure and its determinants in Kenya slum communities. Int J Equity Health. 2015;14(1):1. PMID:25971679

29. Gotsadze G, Zoidze A, Rukhadze N. Household catastrophic health expenditure: evidence from Georgia and its policy implications. BMC Health Serv Res. 2009;9(1):1. PMID:19400939 